\title{
Hepatic and Muscular Presentations of Carnitine Palmitoyl Transferase Deficiency: Two Distinct Entities
}

\author{
FRANCE DEMAUGRE, JEAN-PAUL BONNEFONT, GRANT MITCHELL, NAM NGUYEN-HOANG, \\ ANNA PELET, MARCO RIMOLDI, STEFANO DI DONATO, AND JEAN-MARIE SAUDUBRAY \\ Département de Biochimie, INSERM U75, CHU Necker-75730 Paris Cedex 15, France [F.D., N.N-H.]; Clinique \\ et Unité de Recherche de Génétique Médicale, INSERM U12, Hôpital des Enfants Malades, 149 Rue de Sèvres- \\ 75743 Paris Cedex 15, France [J-P.B., G.M., A.P., J-M.S.]; and Neurometabolic Disease Laboratory, Istituto \\ Neurological "C. Besta," 20133 Milan, Italy [M.R., S.D.D.]
}

\begin{abstract}
Human carnitine palmitoyl transferase (CTP) deficiency results in two different clinical variants, one with "hepatic" and one with "muscular" symptoms. We studied CPT activity and long-chain fatty acid oxidation in fibroblast cell lines from four patients, two from each group. Overall CPT activity was deficient in patients' fibroblasts with the hepatic presentation, as previously demonstrated in patients' fibroblasts with the muscular presentation. The hepatic patients' fibroblasts displayed a $\mathrm{CPT}_{1}$ deficiency which resulted in impaired long-chain fatty acid oxidation. In contrast, $\mathrm{CPT}_{1}$ activity and palmitate oxidation were normal in muscular patients' fibroblasts: In these latter patients, the mutation presumably involved $\mathrm{CPT}_{2}$ activity. These data suggest that CPT deficiency is due to at least two different mutations, resulting in two distinct patterns of clinical and biochemical abnormalities. (Pediatr Res 24: 308-311, 1988)
\end{abstract}

\section{Abbreviation}

CPT, carnitine palmitoyl transferase

Long-chain fatty acids constitute a major source of energy in man. Their oxidation in muscles is essential for energy homeostasis during prolonged exercise (1). During fasting, the oxidation of long-chain fatty acids in liver mitochondria produces ketone bodies, enhances gluconeogenesis, and therefore contributes to the maintenance of normoglycemia (2). CPT (EC 2.3.1.21) controls the transport of long-chain fatty acids into mitochondria. CPT activity is classically considered to be distributed on both the outer $\left(\mathrm{CPT}_{1}\right)$ and the inner $\left(\mathrm{CPT}_{2}\right)$ surfaces of the inner mitochondrial membrane, although this assumption has been recently questioned (3). $\mathrm{CPT}_{1}$ activity is specifically inhibited by malonyl $\mathrm{CoA}$ in animal and human tissues (4-6). Recent data $(3,7-9)$ suggested that $\mathrm{CPT}_{1}$ and $\mathrm{CPT}_{2}$ activities involve two or more distinct proteins.

Human CPT deficiency displays two clinical presentations. Inasmuch as the first description by Di Mauro and Dimauro in 1973 (10), muscular CPT deficiency has been recognized as an important cause of episodic muscle necrosis with paroxysmal myoglobinuria (11). A second clinical presentation associated with liver-CPT deficiency has been documented in a single patient (12) consisting of fasting hypoglycemia with inappro-

Received November 27, 1987; accepted April 29, 1988.

Correspondence and reprints to Dr. France Demaugre, Département de Biochimie, INSERM U75, CHU Necker, 75730 Paris Cedex 15, France. priately low ketogenesis. In this disorder, CPT deficient activity has been demonstrated in liver. However, the defect is probably not limited to the liver because this patient's fibroblasts also exhibited impaired long-chain fatty acid oxidation (13). In the "muscular" presentation, the defect has been demonstrated in all tissues studied, including muscle, liver, leukocytes, platelets, and fibroblasts $(11,14)$. In all these studies, the methodology of CPT assays did not allow a clear discrimination between $\mathrm{CPT}_{1}$ and $\mathrm{CPT}_{2}$ activities. Thus it was not possible to evaluate if the two different clinical presentations resulted from distinct enzymatic defects affecting $\mathrm{CPT}_{1}$ and/or $\mathrm{CPT}_{2}$ activities.

We compared CPT activities and long-chain fatty acid oxidation in four patients' fibroblasts, two with "hepatic" and the other two with "muscular" presentations. Our results suggest that there are at least two varieties of CPT deficiency, each presenting distinct biochemical abnormalities in cultured fibroblasts.

\section{CASE REPORTS}

Case I. The patient was fully reported in 1981 (12). She was referred at 8 months of age for coma with seizures related to hypoglycemia after $16 \mathrm{~h}$ of fasting. She had minimal hepatomegaly without clinical muscular symptomatology or biochemical muscular abnormalities. A 19-h fasting test resulted in a marked hypoglycemia $(1.8 \mathrm{mmol} /$ liter $)$ with deficient ketogenesis $(<0.2$ $\mathrm{mmol} / \mathrm{liter}$ ) reversible by the administration of medium-chain triglycerides. The hepatic histology showed an accumulation of triglycerides, whereas total liver carnitine was normal. Hepatic CPT activity (measured by an "isotope exchange" assay) was greatly reduced. CPT activity was not determined in other tissues but impaired oxidation of palmitate was demonstrated in cultured fibroblasts (13). The child is now $11 \mathrm{yr}$ old and has no clinical or biologic muscular symptoms.

Case II. The patient, a 1-yr-old boy, was referred for hypoglycemic coma. At the end of a 19-h fasting test, blood glucose fell to $1.3 \mathrm{mmol} /$ liter. Blood ketones level was $0.3 \mathrm{mmol} / \mathrm{liter}$, contrasting with blood free fatty acid concentration of $2.5 \mathrm{mmol} /$ liter. Total and free blood carnitine were 55 and $45 \mu \mathrm{mol} / \mathrm{liter}$. Urinary organic acid excretion displayed no abnormal pattern. A liver biopsy was not accepted by the parents. The child is now $10 \mathrm{yr}$ old and no clinical or biologic symptom can be demonstrated.

Case III. The patient has been described previously (15). At the age of $12 \mathrm{yr}$, the boy first experienced muscular cramps and rhabdomyolysis after prolonged physical exercise. Many subsequent episodes of rhabdomyolysis were all induced by prolonged effort, particularly when performed during a fasting test. At the age of $22 \mathrm{yr}$, an identical episode resulted in acute renal failure. 
An ischemic forearm exercise test performed several months after this attack resulted in a normal rise of plasma lactate. The total carnitine content of muscle was not decreased. The CPT activity was markedly deficient in muscle and fibroblasts using the isotope exchange method.

Case IV. The patient has been described (14) and was clinically similar to case III. The CPT defect was demonstrated in muscle and liver without noticeable clinical hepatic symptomatology. Fibroblasts failed to exhibit any CPT defect when tested with forward and isotope exchange assays (described in the case report) but expressed the CPT defect with an assay similar to assay B (Rimoldi M, unpublished data).

\section{MATERIALS AND METHODS}

Fibroblasts were cultured as previously described (13) from controls and CPT-deficient patients. Cell lines I and II were from patients with hepatic presentation and cell lines III and IV from patients with muscular presentation. The oxidation of $5 \mathrm{mM}$ $\left[1,4-{ }^{14} \mathrm{C}\right]$ succinate, $500 \mu \mathrm{M}\left[1-{ }^{14} \mathrm{C}\right]$ octanoate and $100 \mu \mathrm{M}\left[1-{ }^{14} \mathrm{C}\right]$ palmitate was measured as described (13) with modifications (16).

CPT activity was assayed in the $150 \times g$ supernatant of fibroblast homogenates in which mitochondrial integrity was preserved. The homogenization was performed in $150 \mathrm{mM} \mathrm{KCl}$ $50 \mathrm{mM}$ tris, $\mathrm{pH} 7.4$, by sonication (MSE sonicator; medium power; $14 \mu \mathrm{M}$ peak to peak amplitude; $3 \mathrm{~s} ; 4^{\circ} \mathrm{C}$ ). Mitochondrial integrity was assessed by assaying citrate synthase (EC 4.1.3.7) (17) in the supernatant after a $9000 \times g$ centrifugation for 15 min. Usually less than $20 \%$ of the total citrate synthase activity was present in the supernatant.

The assay of $\mathrm{CPT}_{1}$ activity only requires conditions preserving mitochondrial membrane integrity. $\mathrm{CPT}_{1}$ activity is characterized by its total inhibition by malonyl CoA (4). We tested these conditions in assay A, similar to assay 2 of McGarry et al. (4). This assay measured palmitoyl-L-(methyl $\left.{ }^{3} \mathrm{H}\right)$ carnitine production from $\mathrm{L}-\left(\mathrm{methyl}^{3} \mathrm{H}\right)$ carnitine and palmitoyl-CoA. The 550 $\mu$ l incubation mixture contained $115 \mathrm{mM}$ Tris $\mathrm{pH} 7.4 ; 4.5 \mathrm{mM}$ reduced glutathione; $70 \mathrm{mM} \mathrm{KCl} ; 110 \mu \mathrm{M}$ palmitoyl CoA complexed with $1 \%$ fatty acid-free bovine serum albumin (wt/vol), and homogenate. After a 2.5 -min preincubation with and without malonyl $\mathrm{CoA}$, the reaction was initiated by the addition of $540 \mu \mathrm{M} \mathrm{L}-\left(\right.$ methyl $\left.{ }^{3} \mathrm{H}\right)$ carnitine. The actual concentrations of malonyl $\mathrm{CoA}$ added in the preincubation mixture are indicated in figure 1 and Table 1 . The reaction was stopped as described by Solberg (18). $K_{m}$ of $\mathrm{CPT}_{1}$ for carnitine and palmitoyl $\mathrm{CoA}$ was determined on two different control fibroblasts homogenates. At $500 \mu \mathrm{M}$ L-carnitine, $K_{m}$ for palmitoyl CoA was 28 and $23 \mu \mathrm{M} . K_{m}$ for carnitine was 38 and $35 \mu \mathrm{M}$ when determined with $100 \mu \mathrm{M}$ palmitoyl CoA.

The assay of $\mathrm{CPT}_{2}$ activity is hampered by its localization on the inner face of mitochondrial membrane. CPT activity was measured after disruption of mitochondrial membranes with palmitoyl carnitine as a detergent (assays B and C). Assay B was a modification of assay B from McGarry et al. (4). It measured $\mathrm{L}-\left(\right.$ methyl $\left.^{3} \mathrm{H}\right)$ carnitine release from palmitoyl $\mathrm{L}$-(methyl $\left.{ }^{3} \mathrm{H}\right)$ carnitine and $\mathrm{CoA}$ in the absence of albumin. The $210 \mu \mathrm{l}$ incubation

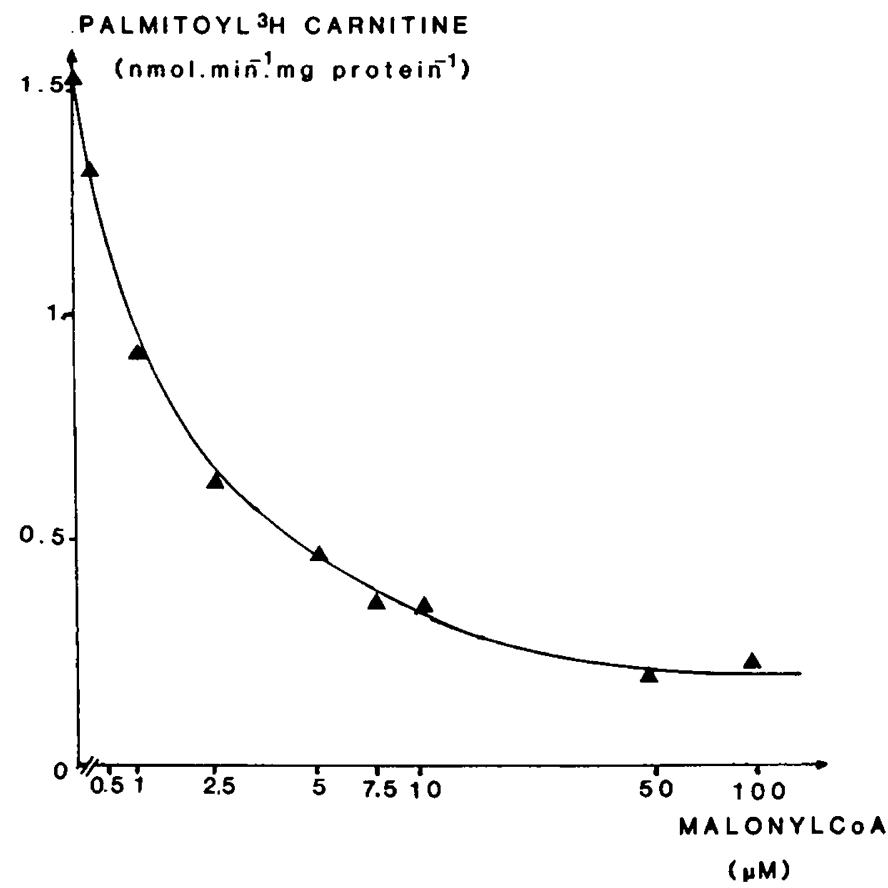

Fig. 1. The effect of malonyl CoA on CPT activity (assay A). Fibroblasts homogenates were preincubated for $2.5 \mathrm{~min}$ with or without malonyl $\mathrm{COA}$ and the reaction was initiated by the addition $\mathrm{L}^{-}{ }^{3} \mathrm{H}$ carnitine. Concentrations of palmitoyl $\mathrm{CoA}$ and $\mathrm{L}-\left(\right.$ methyl $\left.{ }^{3} \mathrm{H}\right)$ carnitine into the assays were 110 and $550 \mu \mathrm{M}$, respectively (for details see Materials and Methods). Results of a typical experiment are displayed. Similar results were obtained with another cell line.

Table 1. CPT activities of patients with hepatic (I and II) and muscular (III and IV) presentations*

\begin{tabular}{|c|c|c|c|c|c|c|}
\hline & \multirow{2}{*}{$\begin{array}{c}\text { Malonyl CoA } \\
50 \mu \mathrm{M} \\
\end{array}$} & \multirow[b]{2}{*}{ Controls } & \multicolumn{4}{|c|}{ Patients } \\
\hline & & & I & II & III & IV \\
\hline \multirow[t]{2}{*}{ Assay A } & - & $\begin{array}{c}2.45 \pm 0.65 \\
(1.45-3.35) \\
N=12\end{array}$ & $\begin{array}{c}0.39 \pm 0.04 \\
n=3\end{array}$ & $\begin{aligned} 0.56 & \pm 0.18 \\
n & =3\end{aligned}$ & $\begin{array}{c}3.18 \pm 0.24 \\
n=3\end{array}$ & $\begin{array}{c}2.86-2.72 \\
n=2\end{array}$ \\
\hline & + & $\begin{array}{c}0.23 \pm 0.06 \\
(0.15-0.31) \\
N=12\end{array}$ & $\begin{array}{c}0.21 \pm 0.05 \\
n=3\end{array}$ & $\begin{array}{c}0.26-0.30 \\
n=2\end{array}$ & $\begin{array}{c}0.30 \pm 0.04 \\
n=3\end{array}$ & $\begin{array}{c}0.22-0.25 \\
n=2\end{array}$ \\
\hline Assay B & & $\begin{array}{c}14.96 \pm 3.37 \\
(11.15-22.7) \\
N=12\end{array}$ & $\begin{array}{c}10.97 \pm 0.41 \\
n=3\end{array}$ & $\begin{array}{c}12.50-11.59 \\
n=2\end{array}$ & $\begin{aligned} 4.28 & \pm 0.53 \\
n & =3\end{aligned}$ & $\begin{array}{c}4.61-4.07 \\
n=2\end{array}$ \\
\hline Assay C & & $\begin{array}{c}2.30 \pm 0.32 \\
N=3\end{array}$ & $\begin{array}{c}2.50 \pm 0.45 \\
n=3\end{array}$ & $\begin{array}{c}2.02-2.28 \\
n=2\end{array}$ & $\begin{aligned} 0.60 & \pm 0.11 \\
n & =3\end{aligned}$ & $\begin{array}{c}0.67-0.63 \\
n=2\end{array}$ \\
\hline
\end{tabular}

* CPT activities were measured in duplicate by three distinct assays (A, B, C) as indicated in Materials and Methods. Assay A (palmitoylcarnitine synthesis) was performed in nondetergent conditions; assay $\mathrm{B}$ (carnitine release), and assay $\mathrm{C}$ (palmitoylcarnitine synthesis) in detergent conditions. Results (mean $\pm 1 \mathrm{SD}$ ) are expressed as nmol of palmitoyl-L-(methyl ${ }^{3} \mathrm{H}$ ) carnitine produced $\cdot \mathrm{min}^{-1} \cdot \mathrm{mg} \mathrm{NCP}^{-1}$ (assay A and C) and as $\mathrm{nmol}$ of $\mathrm{L}-$ (methyl ${ }^{3} \mathrm{H}$ ) carnitine released $\cdot \mathrm{min}^{-1} \cdot \mathrm{mg} \mathrm{NCP}^{-1}$ (assay B). $N=$ number of different control cell lines. $n=$ number of independent experiments performed in deficient strains (each experiment was performed in duplicate). 
medium contained $115 \mathrm{mM}$ Tris $\mathrm{pH} 7.4 ; 70 \mathrm{mM} \mathrm{KCl} ; 8 \mathrm{mM}$ $\mathrm{CoA} ; 4.5 \mathrm{mM}$ reduced glutathione; and homogenate. After a 2.5min preincubation, the reaction was initiated by the addition of $2 \mathrm{mM}$ palmitoyl-L-(methyl $\left.{ }^{3} \mathrm{H}\right)$ carnitine. The reaction was stopped with $0.6 \mathrm{M}$ perchloric acid. After centrifugation, an aliquot of supernatant containing $\mathrm{L}-\left(\mathrm{methyl}^{3} \mathrm{H}\right)$ carnitine was counted in scintillation medium. Assay $\mathrm{C}$ was performed as described (19). It measured palmitoyl-L-(methyl ${ }^{3} \mathrm{H}$ ) carnitine production from $\mathrm{L}-\left(\right.$ methyl $\left.{ }^{3} \mathrm{H}\right)$ carnitine and palmitoyl CoA in the absence of albumin and in the presence of palmitoyl-Dcarnitine in a volume of $500 \mu \mathrm{l}$ containing $40 \mu \mathrm{M}$ palmitoyl CoA, $1 \mathrm{mM}$ L-carnitine, and $1 \mathrm{mM}$ palmitoyl-D-carnitine. The assays were linear with incubation time (3-8 min) and added protein when performed with $50-250 \mathrm{~g}$ protein in assays $\mathrm{A}$ and $\mathrm{C}$ and $50-120 \mathrm{~g}$ protein in assay B. Incubation time was $5 \mathrm{~min}$. Protein was determined by the method of Lowry et al. (20).

CoA, palmitoyl CoA, palmitoyl-L-carnitine, octanoic acid, palmitic acid, succinic acid, and fatty acid-free bovine serum albumin were purchased from Sigma Chemical Co. (St. Louis, MO). Palmitoyl-D-carnitine was synthetized as described (21). L-Carnitine was a gift from Sigma-Tau France. Reduced glutathione was purchased from Boehringer. $\left[1-{ }^{14} \mathrm{C}\right]$ sodium octanoate, [1$\left.{ }^{14} \mathrm{C}\right]$ palmitic acid, $\left[1,4-{ }^{14} \mathrm{C}\right]$ succinic acid, and $\mathrm{L}-\left(\right.$ methyl $\left.{ }^{3} \mathrm{H}\right) \mathrm{car}-$ nitine were purchased from Amersham (UK). Palmitoyl-L(methyl ${ }^{3} \mathrm{H}$ ) carnitine was synthetized as described (22).

\section{RESULTS}

$\mathrm{CPT}_{1}$ activity was identified by its suppressibility by malonyl $\mathrm{CoA}$ (4). In control fibroblasts (Fig. 1), CPT activity measured by assay $\mathrm{A}$ was inhibited by malonyl $\mathrm{CoA}$ in a dose-dependent fashion. The maximum effect ( $90 \%$ inhibition) was obtained with $50 \mu \mathrm{M}$ malonyl CoA. The $\mathrm{I}_{50}$ was approximately $1.2 \mu \mathrm{M}$, similar to values obtained in rat and human fetal liver (6). In cell lines I and II (hepatic presentation), CPT activity measured by assay $A$ was impaired (residual activities 15 and $25 \%$ of control, respectively) (Table 1 ). By contrast, CPT activity measured by this assay was normal in cell lines III and IV (muscular presentation). Inhibition by $50 \mu \mathrm{M}$ malonyl CoA, $\mathrm{V}_{\max }$, and $K_{m}$ for palmitoyl $\mathrm{CoA}$ and L-carnitine were similar to controls in cell lines III and IV (data not shown). In assays B and C, performed in the presence of detergent, cell lines III and IV exhibited an impaired CPT activity (residual activity 25 to $30 \%$ of control). By contrast, in cell lines I and II, CPT activity measured by these assays was normal.

The consequences of impaired CPT activity on the oxidation of fatty acids were studied in intact fibroblasts. In cell lines I and II, the oxidation of palmitate was dramatically decreased, whereas the oxidation of succinate and octanoate (which enters the mitochondria by a CPT-independent mechanism) were nor- mal. Conversely, in cell lines III and IV, long-chain fatty acid oxidation was not reduced, irrespective of the concentration of palmitate used in the experiments and of the presence of $\mathrm{L}$ carnitine. The apparent $K_{m}$ for palmitate was $19.5 \pm 4.5 \mu \mathrm{M}(n$ $=4)$ for controls and $18.3 \mu \mathrm{M}(n=2)$ and $20.5 \mu \mathrm{M}(n=2)$ in cell lines III and IV, respectively.

\section{DISCUSSION}

CPT deficiency with a muscular presentation has been described in nearly 40 patients and has been recently reviewed (11). The clinical presentation is stereotyped. The patient is most often an adolescent male and experiences acute episodes of rhabdomyolisis after prolonged exercise or occasionally after prolonged fasting. Spontaneous attacks are possible but muscle cramps are rare. Acute renal failure can occur during acute attacks. Serum and muscle carnitine levels are not usually decreased but lipid accumulation is occasionally demonstrated in muscle biopsies. CPT deficiency is not restricted to muscle but is also found in all other tissues (e.g. liver, leukocytes, platelets, fibroblasts) studied. The hepatic consequences of this defect are minor and fasting hypoglycemia has not been observed. Ketone body production was delayed during fasting in the few patients thus studied. To our knowledge, patient I represents the only reported case (12) with hepatic presentation of CPT deficiency. Symptomatic hypoketotic hypoglycemia was the main clinical problem. In contrast to patients with long-chain fatty acid oxidation defects, such as systemic carnitine deficiency (23) or long-chain acyl CoA dehydrogenase deficiency (24), heart and skeletal muscle were not affected in patients I and II. Although direct assays in tissues other than liver were not performed, the defect was probably not restricted to liver, because this patient's fibroblasts exhibited a severe impairment of long-chain fatty acid oxidation (12).

These distinct clinical presentations of CPT deficiency could result from distinct mutations affecting either $\mathrm{CPT}_{1}$ or $\mathrm{CPT}_{2}$ activities. The review of the literature failed to answer this question, as the assays used did not discriminate between $\mathrm{CPT}_{1}$ and $\mathrm{CPT}_{2}$ activities. In intact mitochondria, $\mathrm{CPT}$ is known to exist as an overt $\left(\mathrm{CPT}_{1}\right)$ and a latent $\left(\mathrm{CPT}_{2}\right)$ form. The latter is exposed by agents or procedures that disrupt membrane. CPT activity of fibroblasts was measured by three assays (A, B, C), in homogenates in which mitochondrial integrity was preserved (see Materials and Methods). CPT activity, as measured as palmitoyl carnitine synthesis in nondetergent conditions (assay A), was suppressed $(>90 \%)$ by $50 \mu \mathrm{M}$ malonyl CoA, a specific inhibitor of $\mathrm{CPT}_{1}(4)$, suggesting this assay specifically measured $\mathrm{CPT}_{1}$ activity. The assay of $\mathrm{CPT}_{2}$ required treatments that disrupted mitochondrial membranes. This requirement was fulfilled in assays B (used in most published clinical cases) and C, performed in detergent conditions (19). Carnitine release was measured in

Table 2. Oxidation of fatty acids and succinate in fibroblasts from CPT-deficient patients with hepatic (cell lines I and II) and muscular (cell lines III and IV) presentations*

\begin{tabular}{|c|c|c|c|c|c|}
\hline & \multirow[b]{2}{*}{ Controls } & \multicolumn{4}{|c|}{ Patients } \\
\hline & & I & II & III & IV \\
\hline$\left[1-{ }^{14} \mathrm{C}\right]$ palmitate & $\begin{array}{c}2.98 \pm 0.88 \\
(2.06-4.49) \\
N=24\end{array}$ & $\begin{array}{c}0.186 \pm 0.25 \\
n=6\end{array}$ & $\begin{array}{c}0.802 \pm 0.17 \\
n=4\end{array}$ & $\begin{array}{c}2.18 \pm 0.25 \\
\quad n=4\end{array}$ & $\begin{array}{c}2.36 \pm 0.44 \\
n=8\end{array}$ \\
\hline$\left[1-{ }^{14} \mathrm{C}\right]$ octanoate & $\begin{array}{c}0.85 \pm 0.30 \\
(0.52-1.40) \\
N=12\end{array}$ & $\begin{array}{c}0.95 \pm 0.31 \\
n=3\end{array}$ & $\begin{array}{c}0.82 \pm 0.21 \\
n=3\end{array}$ & $\begin{array}{c}1.48 \pm 0.36 \\
n=3\end{array}$ & $\begin{array}{c}1.63 \pm 0.50 \\
n=3\end{array}$ \\
\hline$\left[1-{ }^{14} \mathrm{C}\right]$ succinate & $\begin{array}{c}2.31 \pm 0.52 \\
(1.71-3.79) \\
N=12\end{array}$ & $\begin{array}{c}1.80 \pm 0.43 \\
n=3\end{array}$ & $\begin{array}{c}2.12 \pm 0.34 \\
n=3\end{array}$ & $\begin{array}{c}4.185 \pm 0.68 \\
n=3\end{array}$ & $\begin{array}{c}2.52 \pm 0.34 \\
n=3\end{array}$ \\
\hline
\end{tabular}

\footnotetext{
${ }^{*}$ Results (mean $\pm 1 \mathrm{SD}$ ) are expressed as nanomoles of radioactive product. $\mathrm{h}^{-1} \cdot 10^{6}$ cells. $N=$ number of different control cell lines. $n=$ number
} of independent experiments performed in deficient strains (each experiment was performed in duplicate). 
assay B and palmitoyl carnitine synthesis was measured in assay C. Although these assays are supposed to investigate total $(1+$ 2) CPT activity, D- and L-palmitoyl carnitine used as detergents in assays $\mathrm{B}$ and $\mathrm{C}$ also inhibited a fraction of CPT activity, presumably $\mathrm{CPT}_{1}$ activity (7-9). As a consequence, assays B and $\mathrm{C}$ likely measure $\mathrm{CPT}_{2}$ activity only.

We studied CPT activities in four patients' fibroblasts, two of them presenting the hepatic form and the other two the muscular form. Patients' cell lines with hepatic presentation exhibited a defective $\mathrm{CPT}_{1}$ activity. Conversely, in these cells, CPT activity was not impaired when measured in detergent conditions, suggesting an intact $\mathrm{CPT}_{2}$ activity. In patients' cell lines with muscular presentation, assay $\mathrm{A}$ failed to evidence a decreased activity, irrespective of the concentration of albumin $(0.1$ to $1 \%)$ and palmitoyl CoA (10 to $300 \mu \mathrm{M}$ ) used in the assay (data not shown), contrasting with Zierg and Engel's results (25). They demonstrated an impaired CPT activity in muscle mitochondria from muscular presentation patients in an assay similar to assay $\mathrm{A}$ performed with $0.1 \%$ albumin and $200 \mu \mathrm{M}$ palmitoyl CoA. This discrepancy between our data and those of Zierg and Engel (25) might be due to differences in the cellular material used (intact fibroblast mitochondria yersus disrupted muscle mitochondria). However, CPT activity of "muscular" cell lines was markedly reduced when measured in detergent conditions, in agreement with earlier data $(15,25)$; indeed, muscular CPT deficiency was usually shown under such conditions. Thus the impaired CPT activity measured by assays $B$ and $C$ could be explained by a defect of $\mathrm{CPT}_{2}$ activity. These data show that the two clinical forms of CPT deficiency are caused by different mutations. As we only studied two cases of each clinical presentation of CPT deficiency, investigations of other patients must be performed to establish a firm correlation between clinical and biochemical data.

The metabolic consequences of CPT deficiency also differentiated muscular and hepatic cell lines; only the latter exhibited reduced long-chain fatty acid oxidation. These data might be compared with clinical consequences of CPT defects in hepatic and muscular forms. It was striking that, despite liver CPT deficiency in both forms (4), hypoketotic hypoglycemia only occurred in the hepatic form. These data suggest that $\mathrm{CPT}_{1}$ activity determines overall fatty acid oxidation in fibroblasts and liver as well. The lack of muscular symptoms in the hepatic presentation is puzzling. Along this line, we hope to perform muscle biopsies in our two hepatic patients in order to measure muscular CPT activities.

\section{REFERENCES}

1. Ahlborg C, Felig P, Hagenfeldt L 1974 Substrate turnover during prolonged exercise in man: splanchnic and leg metabolism of glucose, free fatty acids and amino acids. J Clin Invest 53:1080-1090

2. Mc Garry JD, Foster DW 1980 Regulation of hepatic fatty acid oxidation and ketone body production. Annu Rev Biochem 49:395-420

3. Murthy MSR, Pande SV 1987 MalonylCoA binding site and the overt carnitine-palmitoyltransferase reside on the opposite sides of the outer mitochondrial membrane. Proc Natl Acad Sci USA 84:378-382

4. Mc Garry JD, Leatherman GF, Foster DW 1978 Carnitinepalmitoyltransferase I. The site of inhibition of hepatic fatty acid oxidation by malonylCoA. J Biol Chem 253:4128-4136

5. Saggerson ED, Carpenter CA 1981 Carnitine palmitoyl transferase and carnitineoctanoyltransferase activities in liver, kidney cortex, adipocyte, lactating mammary gland, skeletal muscle and heart. Relative activities, latency and effect of malonyl CoA. FEBS Lett 129:229-232

6. Mc Garry JD, Mills SE, Long CS, Foster DW 1983 Observations on the affinity for carnitine and malonylCoA sensitivity of carnitinepalmitoyltransferase I in animal and human tissues. Biochem J 214:21-28

7. Declercq PE, Falck JR, Kuwajima M, Tuminski H, Foster DW, Mc Garry JD 1987 Characterization of the mitochondrial carnitine palmitoyltransferase enzyme system 1. Use of inhibitors. J Biol Chem 262:9812-9821

8. Woeltje KF, Kuwajima M, Foster DW, Mc Garry JD 1987 Characterization of the mitochondrial carnitine palmitoyl transferase enzyme system. J Biol Chem 262:9822-9827

9. Lund H 1987 Carnitine palmitoyltransferase: characterization of a labile detergent-extracted malonylCoA sensitive enzyme from rat liver mitochondria. Clin Chim Acta 918:67-75

10. Di Mauro S, Dimauro PMM 1973 Muscle carnitinepalmitoyltransferase deficiency and myoglobinuria. Science 182:929-931

11. Di Mauro S, Trevisan C 1982 Carnitine palmitoyl transferase (CPT) deficiency: a review. In: Schotland DL (ed) Disorders of the Motor Unit. John Wiley and Sons, New York, pp 657-665

12. Bougneres PF, Saudubray JM, Marsac C, Bernard O, Odièvre M, Girard J 1981 Fasting hypoglycemia resulting from hepatic carnitinepalmitoyltransferase deficiency. J Pediatr 98:742-746

13. Saudubray JM, Coude FX, Demaugre F, Johnson C, Gibson KM, Nyhan WL 1982 Oxidation of fatty acids in cultured fibroblasts: a model system of the identification and study of defects in oxidation. Pediatr Res 16:877-881

14. Di Donato S, Castiglione A, Rimoldi M, Cornelio F, Vendemia F, Gardace G, Bertagnolio B 1981 Heterogeneity of carnitinepalmitoyltransferase deficiency. J Neurol Sci 50:207-215

15. Di Donato S, Cornelio F, Pacini L, Peluchetti D, Rimoldi M, Spreafico S 1978 Muscle carnitinepalmitoyltransferase deficiency in cultured fibroblasts. Ann Neurol 4:465-467

16. Mitchell G, Saudubray JM, Pelet A, Bemaugre F, Labarthe JC 1984 The effects of carnitine on palmitate oxidation in cultured fibroblasts. Clin Chim Acta 143:23-27

17. Saggerson ED, Carpenter CA, Tselentis BS 1982 Effects of thyroidectomy and starvation on the activity and properties of hepatic carnitinepalmitoyltransferase. Biochem J 208:667-672

18. Solberg ME 1972 Different carnitinepalmitoyltransferases in calf liver. Biochim Biophys Acta 280:422-433

19. Stakkestad JA, Bremer J 1983 The outer carnitinepalmitoyltransferase and regulation of fatty acid metabolism in rat liver in different thyroid states. Biochim Biophys Acta 750:244-252

20. Lowry OH, Rosebrough NJ, Farr AL, Randal RJ 1951 Protein measurement with the folin phenol reagent. J Biol Chem 193:265-275

21. Bremer J 1968 Long-chain acylcarnitines. Biochem Prep 12:69-73

22. Murthy MSR, Pande SV 1984 Mechanism of carnitine acylcarnitine translocase-catalyzed import acylcarnitines into mitochondria. J Biol Chem 259:9082-9089

23. Rebouche CJ, Engel AG 1983 Carnitine metabolism and deficiency syndromes. Mayo Clin Proc 58:533-540

24. Hale DE, Batshaw ML, Coates PM, Frerman FE, Goodman SI, Singh I, Stanley CA 1985 Long-chain acylCoenzymeA dehydrogenase deficiency: an inherited cause of nonketotic hypoglycemia. Pediatr Res 19:666-671

25. Zierg S, Engel AG 1985 Regulatory properties of a mutant carnitinepalmitoyltransferase in human skeletal muscle. Eur J Biochem 149:207-214 